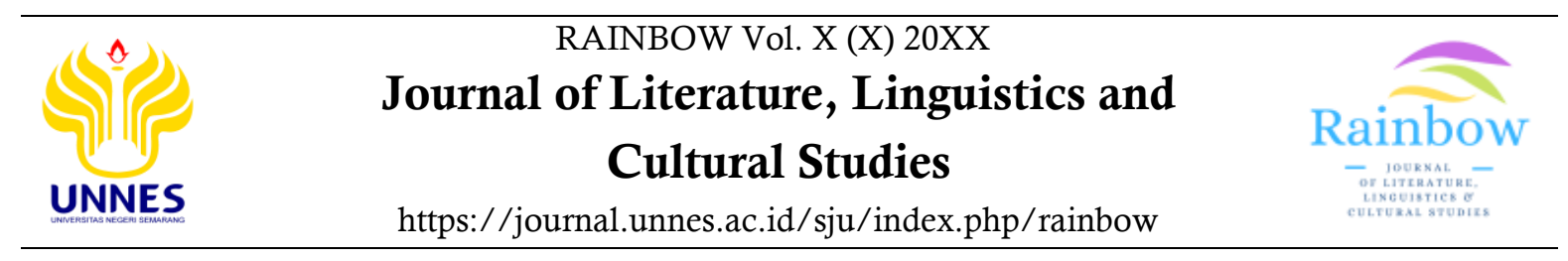

\title{
Sugiharti Halim (2008): A cinematic portrayal of Chinese Indonesian's ambiguous identity
}

Christina $^{\square}$

Master's Program in Literature, Petra Christian University Surabaya, Indonesia

\begin{tabular}{|c|c|}
\hline Article Info & Abstract \\
\hline $\begin{array}{l}\text { Article History: } \\
\text { Received } \\
\text { 04 July } 2021 \\
\text { Approved } \\
12 \text { October } 2021 \\
\text { Published } \\
30 \text { October } 2021 \\
\text { Keywords: } \\
\text { Chinese Indonesian, Indie } \\
\text { films, liyan, assimilation, } \\
\text { mise-en-scene }\end{array}$ & $\begin{array}{l}\text { Sugiharti Halim (2008) provides a cinematic insight into the lives of Chinese Indonesians } \\
\text { whose identities are perpetually labeled as liyan (other) in the eyes of the inlanders } \\
\text { (pribumi). It narrates the story of Sugiharti Halim, a Chinese Indonesian girl, who } \\
\text { struggles with her Indonesian sounding name which, instead of successfully } \\
\text { assimilating her Chinese identity, makes her even more Chinese than before. This study } \\
\text { aims to investigate the cinematic portrayal of Chinese Indonesian's ambiguous identity } \\
\text { as experienced by the female protagonist. The writer employs close textual analysis of } \\
\text { the indie film by the reading of cinematic codes (mise en scene) and the theoretical } \\
\text { perspective of name giving developed by Watzlawik in } 2016 \text {. The conflict highlited in } \\
\text { this "indie" criticizes the position of Chinese filmmaker for being pigeonholed on the } \\
\text { ground of their ethnicity. Therefore, the study reveals that films have become a new } \\
\text { means of politicizing the interest of certain ethnic group which puts Chinese } \\
\text { Indonesians in their most vulnerable position. The study concludes that independent } \\
\text { films help the young Chinese filmmakers to reconnect with their Chinese heritage as } \\
\text { they begin to bits of their Chineseness which were previously misconstrued by the } \\
\text { inherited ideals of the New Order regime. }\end{array}$ \\
\hline
\end{tabular}

C Copyright 2021

How to cite (in APA Style):

Christina, C. (2021). Sugiharti Halim (2008): A Cinematic Portrayal of Chinese Indonesian's Ambiguous Identity. Rainbow: Journal of Literature, Linguistics and Culture Studies, 10(2), 59-68. https://doi.org/10.15294/rainbow.v10i2.47963

\section{INTRODUCTION}

The discourse on Chinese Indonesians has, from time to time, invoked numerous controversies over their ambiguous identities. On the one hand, they have been perpetually "othered" by the non-Chinese (pribumi), while at the same time, they have somewhat become a product of hybridity through a long process of intermarriage with the locals or the adoption of Indonesian-sounding names. Despite the laborious attempt to localize their Chinese identity, they are still labeled as "perpetual foreigner" due to the past ideologies inherited from the New Order regime in

\footnotetext{
Corresponding author:

Jalan Siwalankerto 121-131, Surabaya, 60236, Indonesia

E-mail: a21200001@john.petra.ac.id
}

the 1960 's, whereby they were allegedly suspected as victims of suppression for their strong allegiance with their homeland. The hallmark of their existence was addressed as "Masalah Cina" otherwise known as the Chinese problem by the New Order politicians, in which case they were stripped off their cultural bonds and political right.

They were, in every respect, restricted from their expression of Chineseness in all public domains namely schools, media, and most importantly their cultural practices (Hoon, 2017). After decades of cultural scrutiny and oppression, the Chinese Indonesian were able to see at least a glimpse of hope from the reinstatement of Chinese p-ISSN: 2252-6323 e-ISSN: $2721-4540$ 
Indonesian cultural heritage in by President Abdurrahman Wahid (Gusdur) in 1998 which open a floodgate of opportunities for the Chinese Indonesians to re-express their cultural practices in religion, education, language, and media. The subject of Chinese Indonesian is not a novelty for the latter category. They have been previously featured in many other commercial films like Meilan Aku Cinta Padamu in the 1970's and well into 1980's in a classic romance like Putri Giok. Even the more contemporary box offices like Ernest Prakasa's Ngenest (Thaniago, 2017). It is not until late 2008, that filmmakers began to portray the discourse of Chinese Indonesian in an honest way by means of a new filming medium of Independent film (Indies).

Several studies have previously brought upon the issues of Chinese Indonesians' ambivalent identity as referenced from Tintin Wulia, a Chinese Indonesian artist who lives as a diaspora in Melbourne. The contribution to the embedded issue of Chinese Indonesian ambiguous identities in independent films can be explained by Wulia (2008) in her essay addressing the social tension and discrepancies between the Chinese Indonesians and the inlanders (pribumi) despite the adoption of Indonesian names by the Chinese which she later dubs as "the name game". This study challenges the Chinese Indonesian filmmakers and artists alike to renegotiate the less exposed problem of failed Chinese Indonesian assimilation which also serves as the inspiration of Ariani Darmawan's indie, Sugiharti Halim (2008).

Following the ever-increasing interests in the discourse of Chinese Indonesian, in 2016, Charlotte Setijadi examined the depiction of Chinese Indonesians in national films and its attempt to recuperate the sense of Chinese heritage of the Chinese Indonesian filmmakers. Setijadi argued that media in this sense was used to immortalize the negative portrayals of Chinese Indonesians as well as to project their sense of "otherness". The same is true for films which were primarily harnessed by the New Order regime as a means of control and manipulation to promote his government. Because of this, the Chinese were as though banished completely from their involvement in the national cinema. A similar Chinese fever also struck the film making industry with the film makers highlighting the lives of Chinese Indonesians as the central theme as they also began to approach the issue of Chinese Indonesians identities. She concludes that postreformation opens up more ways for the national cinema to revisit the previously taboo topics regarding the existence of Chinese in Indonesia (Setijadi, 2013).

Another study on Sugiharti Halim was further elaborated by Nuraeni in 2017 detailing the double discrimination that the female protagonists' experiences for being a Chinese Indonesian and a woman in Indonesian patriarchal society. She particularly compares the identities of two women of different ethnicities. This study emphasizes on how women have always become the subject of discrimination in most Indonesian films. However, the past discrimination is what eventually inspires a number of female filmmakers, with Ariani Darmawan being one of them, to mark their grand entrance to the male-dominated film industry as they subvert the subject-object positioning of the two female characters in the movie whereby women are not forever confined in their sense of "otherness" regardless of their ethnicities.

The latest reference on Sugiharti Halim is generated from Rokhani (2020) which explores the concept of Chinese-ness as a cultural product as commercially depicted in national movies of the post New Order. The Chinese Indonesian filmmakers are thus given the means to communicate their inner thoughts and feelings about being situated as "other" in dealing with the stereotypical images associated with the Chinese Indonesians, providing an insight of being drawn into the story and exploring "the less explored world of the Chinese Indonesians" in national cinema.

However, none of the above studies examine the issues of Chinese Indonesian's identity by means of cinematic codes (mise en scene), and that is why this study aims to explore various cinematic means that the Chinese Indonesian filmmaker, Arianti Darmawan has used to powerfully communicate the protagonist's conflict 
of her identity crisis through symbolic representations of her cultural roots in the series of montages and the cinematic arrangement of the point of view (POV), lighting, camera works, and also costumes. It is also intriguing to learn that indie movie such as this one has become a new medium of cinematic expression of the Chinese Indonesian filmmakers' sense of Chineseness that they are unable to convey in the more successful and commercial films. Through the close reading of the cinematic codes (mise-en-scene) embedded in the film, the writer breaks down the female protagonist's lifelong struggle in dealing with her "in-between" identity, where on the one hand she is not fully a Chinese (only by association with her Chinese root). On the other hand, she is also not fully acknowledged for her Indonesian citizenship and still become the subject of marginalization by the inlanders (pribumi). Therefore, the current study addresses the cinematic depiction of Chinese Indonesians' identity and all its complexities beyond the local domain as a serious discourse experienced by the world over.

The new cinematic medium has shed light upon a different side of Chineseness regarding their traumatic experience of May 1998 or their ambiguous identity which were too dramatized in the more commercial films. In this study, the writer would like to approach the issue of Chinese Indonesian identity featured in Sugiharti Halim (2008), an internationally acclaimed indie film directed by Ariani Darmawan with a closer look into the significance of name giving in justifying Chinese Indonesian's identity. I would also like to further my argument that indie film such as this one has become a new means for the Chinese Indonesian filmmakers of these days to remedy the misconstrued stereotypes of the Chinese Indonesians and to reconnect with the previously suppressed bits of their Chinese roots.

\section{METHODS}

Methodologically, this study was conducted in a close textual analysis of the female protagonist, Sugiharti Halim and another Chinese Indonesian supporting character, Tan Ging Le. This study is concerned with the cinematic reading of mise en scene which comprises all on-screen visual elements, including lighting, costumes and makeups, framing, and camera angles used by the filmmaker to visually communicate the unspoken message of Chinese Indonesians' ambivalent identities. On this ground, the writer carefully selected the protagonists' actions and utterances as depicted in the still images of film montages from Sugiharti Halim (2008) to help illustrate the argument in this study. As for the secondary data, the writer cited several readings of related books and journal articles addressing the issues of Chinese Indonesian ambiguous identity in media. The discussion of the protagonists' conflict with their Chinese Indonesian identity is later supported using the cinematic perspective of the mise-en-scene, the historical context of Chinese Indonesians, and theoretical basis of name giving as developed by Watzlawik et al (2016).

\section{RESULTS AND DISCUSSION}

\section{Constructing Sugiharti's ambiguous identity by means of montage series}

Sugiharti Halim (2008) primarily highlights the never-ending issue of Chinese Indonesians' ambiguous identity; in which case, the Chinese have been forever labelled as "perpetual foreigner" or "newcomers" in the eyes of the Pribumi (Setijadi, 2016). The impure nature of their whole being poses a threat to the ruling New Order who later subjected them for being "Masalah Cina" (The Chinese Problem). The only way of addressing the Chinese problem, therefore, was through means of assimilation and the absorption of Chinese culture into Indonesian. In 1966, the leader of New Order regime, Suharto issued a presidential decree noted as follows:

Indonesian citizens who still use Chinese names, and who wish to change their names to conform to indigenous Indonesian names, need p-ISSN: 2252-6323 e-ISSN: 2721-4540 
to be given the fullest facilities by implementing

a special procedure. (Kepres no. 127/u/kep1966)

forcing the Chinese Indonesians to discard all the Chinese attributes of their names and replaced it with a more Indonesian sounding ones which were similar to the local people's names, e.g. Gunawan, Sugiharto, Hartono, or Hartawan for those residing in Java. The majority of Chinese Indonesians also still wanted to preserve bits of their Chineseness in their new name, therefore, a person whose Chinese name was Liem may adopt an Indonesian name like Halim or Liemanta, for instance. The assiduous process of assimilation and name changing policy, however, did not completely erase their "Chineseness" in the eyes of the government.

All Chinese Indonesians who have adopted an Indonesian-sounding names, therefore, were still required to keep the records of their former Chinese names in any government related affairs (Lie \& Bailey, 2017). Such historical record has inspired Ariani Darmawan, also a Chinese Indonesian filmmaker to immortalize the struggle and hardships that Chinese Indonesians, which is cinematically represented by Sugiharti Halim, regarding the choice of their Indonesian names. The film begins with a rather dark, gloomy background with Sugiharti Halim seated in the center, holding a cigarette, as she addresses the viewers of the unpleasant experiences she has had with her Indonesian name in a somewhat laid-back attitude. She immediately blames her parents for choosing a silly-sounding Indonesian name like Sugiharti for her. The film opening suggests Sugiharti's emotional standpoint for being one of those Chinese Indonesians who is still somehow treated differently by her fellow pribumi despite the adoption of her Indonesian name. Her laid back gesture, on the one hand, hints at the satirical nature of this indie film the filmmaker intended to bring throughout the film.

On the other hand, it may also project her long-held anger and mockery towards the failed assimilation policy. The filmmaker has somewhat presented the viewers with a powerful start, hinting them out that this indie film was not made to gratify the viewers' need for entertainment.
Although it was meant as a comedy, it also addresses a rather serious and sensitive discourse of Chinese Indonesians' identity that the viewers must not take too lightly. The strength of this film lies primarily in the use of montage, or a quick insertion of still/moving image in a continuous sequence (Bordwell et al., 2013) in order to contain the 40 years + of Chinese Indonesian history in a 10 -minute film. The montage somehow helps in providing all the necessary backstory of Sugiharti's intragenerational experiences like her father, Tan Ging Le (one of her dinner dates), and also Tan Ging Le's father who practically share similar cases of ethnical prejudices and stereotypes growing up as Chinese Indonesians. The montages briefly, yet vividly narrate the inner and outer experiences that shapes Sugiharti's perception on her Indonesian name, which the writer personally also finds effective to make this 10- minutes-film somewhat more grandeur than its cinematic packaging. Sugiharti Halim centralizes the discourse of name-giving, in which case has tremendously steered over Sugiharti's perception of her Chinese identity and her fragile position as a Chinese Indonesian.

Allport (cited in Joubert 1993) contended that names or self-labels are the most crucial marker of someone's identity. This notion was further elaborated by Walton that name giving and all the process that entails is considered be a determining factor in the individual's development of personality (Watzlawik et al., 2016). Throughout the movie, Sugiharti expresses her utter discontentment over her silly Indonesian name to her dinner dates, which include two pribumi and one Chinese Indonesian date, Tan Ging Le. The reason underlying her choice of name is somewhat unclear and it was simply done out of rush and emergency by her father, Taruna Halim (Lim Oen Hoek) following the assimilation policy at the time of her birth which imposed all Chinese to leave out the attributes of their Chinese identity in their names and cultural practice if they wished to stay as an Indonesian citizen (Lie \& Bailey, 2017).

On this ground, the filmmaker has cleverly employed the first series of montage depicting 
various inner experience Sugiharti has had with her Indonesian name which influences her to renegotiate her Chinese Indonesian identity. It begins with Sugiharti addressing her first date, a pribumi about the inquiry she makes on the meaning of her Indonesian name.

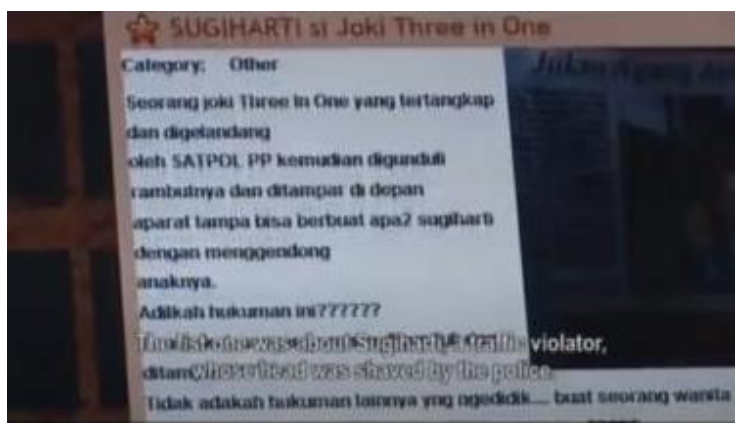

Figure 1. A still montage one on web inquiry

To her surprise, she learns that her Indonesian name does not carry any significant meaning at all, as opposed to what she initially expected (the female name "Sugiharti" may suggest that her parents wished she would grow up surrounded by wealth). Herzfeld (1982) argued initially parents might project certain values or characteristics to naming process. Nevertheless, he also added parents will not treat the children in accordance with these values they have attached in their names. On the contrary the child give a new meaning to their names as they get older, so that it gradually replaces the previous values (Watzlawik et al., 2016). The female version of her name "Sugiharti" is, in fact, often associated with criminal records (name of female murder convict or someone who became a murder victim).

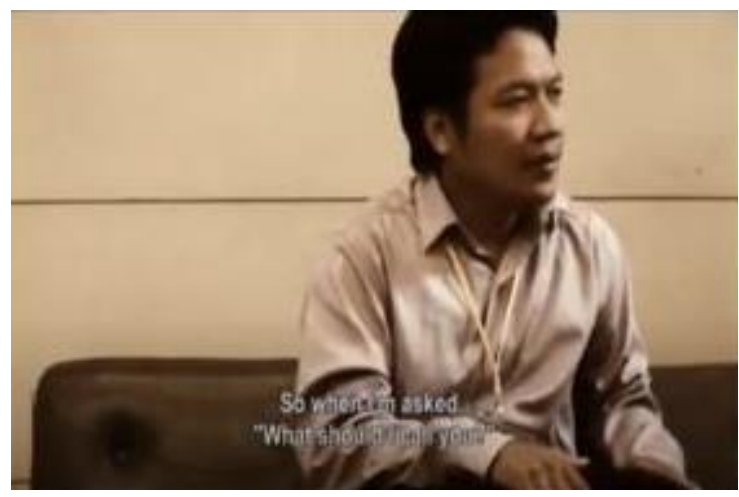

Figure 2. A still montage on a man making fun of Sugihart's Indonesian name.

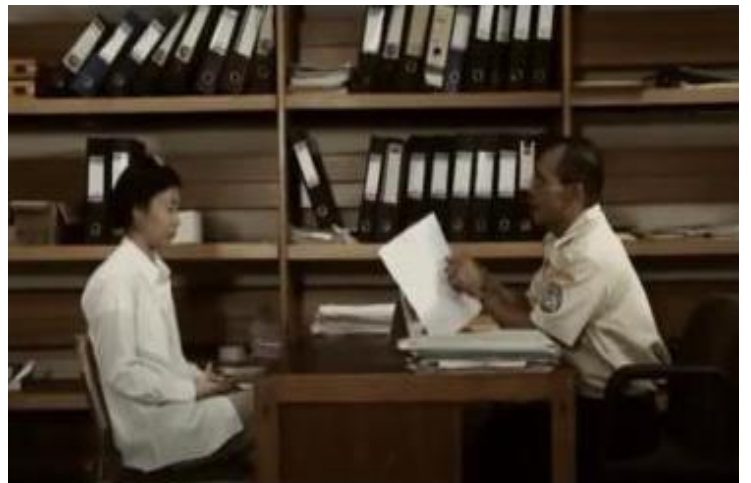

Figure 3. A still montage displaying Sugiharti's being interrogated by an immigration officer.

The montage is quickly rerouted to the starting scene, whereby Sugiharti directly ask her date (or rather the viewers) whether she really deserves such Indonesian name. The next montage follows a video addressing another thing Sugiharti dislikes about her name. It shows a male pribumi deliberately asks her whether her name is made out of "deep thoughts" or "out of fun" which irritates Sugiharti. No music was added into the montage video, so the only sound the viewers can hear is that of Sugiharti's, cynically mimicking the actor's speech in her irritating tone which adds humor to the serious scene.

The same technique applies to the next montage with Sugiharti being interrogated by an immigration officer who vehemently demands her to hand over her father's SBKRI (Proof of Indonesian Citizenship) and Surat Bukti Ganti Nama. These two documents are certainly artefacts of sentimental values for most Chinese Indonesians, especially the elder generation who would be very reluctantly reveal traces of their Chinese citizenship to anyone (Lie \& Bailey, 2017) which also gives a greater sense of authenticity to the general viewers who has previously never seen those documents. Sugiharti's gesture of showing excerpts of these documents, therefore, suggests the failure of assimilation policy which could never completely erase the evidence of her past ethnical prejudice even after the effort the Chinese Indonesians have made in the adoption of their Indonesian names. The outcome was a lot worse than expected; instead of being fully acknowledged 
for their Indonesian citizenship, they still become the subjects of marginalization by the pribumi.

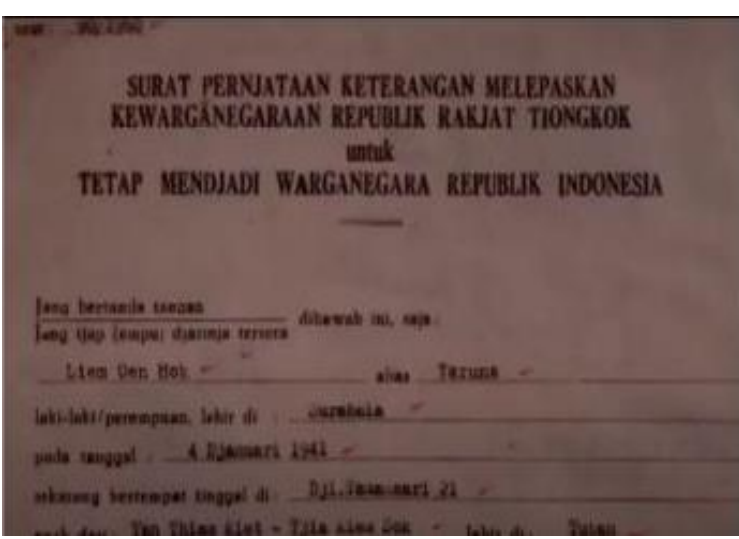

Figure 4. A still montage displaying Surat Pernyataan Ganti Nama addressed to the Chinese Indonesians

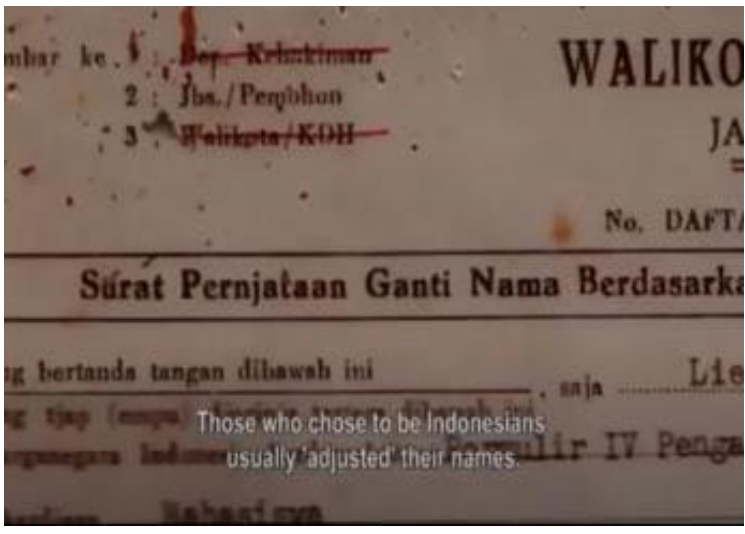

Figure 5. A still montage displaying certificate for relinquishing Chinese citizenship

The adoption of Indonesian names, all in all,has made them even more Chinese than before. By using montage sequences, the filmmaker successfully addresses the limitation of the cinematic medium by incorporating the narrative element which contains the backstory of Sugiharti's inner experience and the properties (props) signifying the identities of Chinese Indonesians at the same time. Besides, such filming technique also provides a lighter, comical air in the way it presents a serious, sensitive issue like Chinese Indonesians' identity without having to put too much drama into the scenes. Unlike the typical montage sequence which is characterized by the lack of dialogue and is only wrapped in music (Bordwell et al., 2013), in this indie;however, the filmmaker aims to emphasize the narration through the insertion of Sugiharti's voice over in the montage clips, making her the focal point, the center of attention through whose voice the identities of other Chinese Indonesians are being narrated.

The next part of the montage features a different perspective of Chinese identities from another Chinese Indonesian in this film, Tan Ging Le, who also happens to be one of Sugiharti's dinner dates. The viewers can almost immediately feel a change of tone, from Sugiharti's accusing gesture in the previous montage to the more accepting Tan Ging Le which also poses as a contrast of the two characters in the way they perceive the ethnic discrimination surrounding their Chinese Indonesian identities. The filmmaker employed the same montage sequence to highlight flashbacks of Tan Ging Le's inner experience in positively accepting his Chinese identity. The sequence begins with an old photograph of Ging Le's childhood as he narrates the source of inspiration where he got his Chinese name, which was derived from Confucian teaching. Because of his father's admiration on the teaching, he included a certain value of Confucian teaching in the naming of his three sons. This is mainly suggested from the fact that the practice of name giving is utterly important in the Chinese culture. The Chinese traditionally believed that given name would induce the qualities like riches, bravery, or intelligence inherent in the name (Seeman, 1980). In the peak of assimilation policy, where most Chinese Indonesians were left with no choice but to discard their Chinese name and adopt a more Indonesian sounding one, his father stood firm on his decision to stick with his Chinese name.

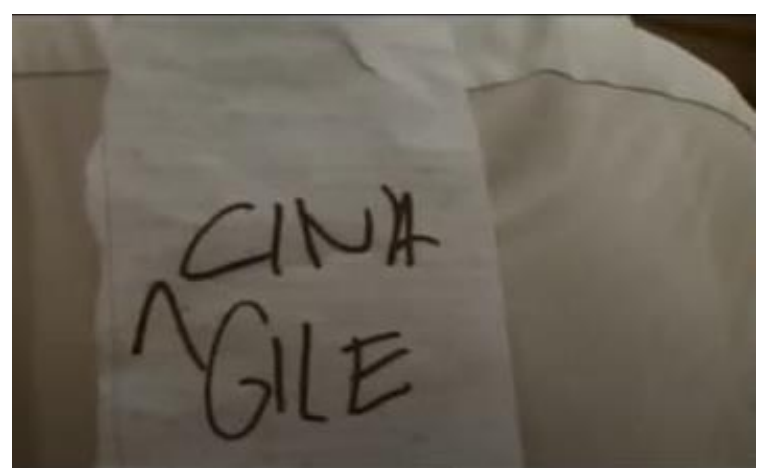

Figure 6. A still montage displaying insults addressed to Tan Ging Le for his Chinese sounding name 
Again, the emphasis is more on Tan Ging Le's narration; therefore, the filmmaker deliberately eliminated the music and replaced it with Tan Ging Le's voicing over the other characters in featured in this montage, namely his father and his friends, as though Ging Le was addressing his story directly to the viewers. Such technique has held considerable impacts on the viewers, especially Chinese Indonesian ones who could relate their feeling and perception on their Chinese identities with that of Tan Ging Le's.

The montage sequence also briefly shows a footage from Ging Le's school days, whereby he was bullied by his pribumi friends for his Chinese name. A quick transition of sketches containing Ging Le's insulting nick names like Tukang Gule, Gile, Gingsul, and also the pinnacle of this insult, Cina Gile, which triggered his rage and disappointment towards his pribumi friends. Both the filmmaker and the viewers have benefited greatly from the use of montage sequence in this indie film, where on the one hand, it allows the filmmaker to put more emphasis on the event of Ging Le's school days, a turning point in his life that changes his perspective on his pribumi friends once and for all. He begins to see how fragile his position is as a Chinese Indonesian, who does not adopt an Indonesian name, thereby, literally marking him as a liyan or perpetual foreigner.

The filmmaker, on the other hand, also made the best use of the cinematic medium, when she decided to minimize the use of extras (supporting actors) so that the focus could be, instead, directed to Ging Le's narration and the picture/footages included in the montage which, in every respect, suggest that the problem of Chinese Indonesian's ambiguous identity remains unresolved even with the revitalization of Chinese culture by Gusdur in 1998. The assimilation policy has imprisoned them in their Chineseness as the name adoption makes it easier for the pribumi to categorize and eventually marginalize them as Chinese Indonesians (Setijadi, 2016).

\section{MISE-EN-SCENE}

Potrayal of Sugiharti's Ambigous Identity by means of POVs and Camera Works

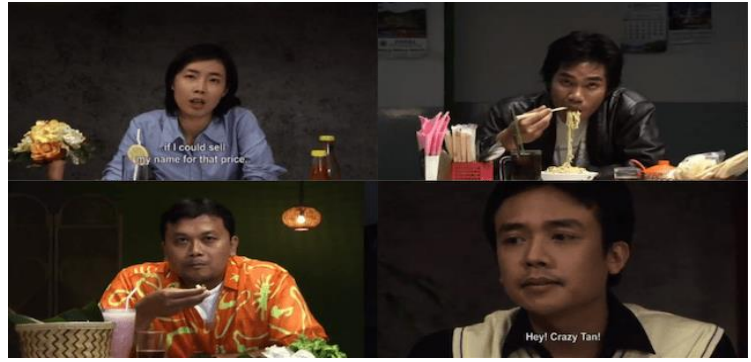

Figure 7. a movie still displaying various POVs used by the filmmaker

The stage arrangement / mise-en-scene also contributes to the projection of Chinese Indonesian identities in this 10-minute film. The filmmaker has managed to make this short movie somewhat grandeur than its cinematic packaging by optimizing the carefully selected scene arrangements which include POV (Point of View), costumes and make-up, and camera works. The writer shall begin my analysis on the matter from the $\mathrm{POV} /$ perspective through which this narration is told in this film. POV in this respect is intended to highlight the characters' attitudes and to channel their unspoken emotions. Throughout the film, the story is extensively captured from Sugiharti, Tan Ging Le, and the pribumi dinner dates' subjective point of view which allows the viewers to notice a variety of facial expressions and emotions that each character display on the camera as well as to delve into the characters' stream of consciousness and their unspoken gestures (Lewis, 2014).

For instance, the filmmaker deliberately and quite extensively switches from the first (the pribumi dinner dates on frame) to second person point of view (Sugiharti/Tan Ging Le on frame). Through Sugiharti's optical standpoints, the viewers could tell how indifferent and uninterested the pribumi were, upon hearing Sugiharti's story. No dialogue was added in the scene. The pribumi dates were simply too occupied with finishing their food as they occasionally throw cynical stare at Sugiharti. They did not grow up with the same experience as that of Sugiharti's, therefore, Sugiharti's complaints will not affect them in any way. The contrasting gestures translates the invisible border the pribumi has established towards the Chinese Indonesians which also implies that even with the adoption of Indonesian name, 
Sugiharti is still cynically viewed as a liyan in the eyes of her pribumi dates.

Even on such dating occasion, Sugiharti is unable to completely mingle with the pribumi dates. The changing of POV from Sugiharti to Tan Ging Le's subjective standpoint also informs the viewers on the changing of mood. Through a second person POV (Ging Le on frame), for instance, the viewers can immediately notice Tan Ging Le's amiable and tolerant air who has been patiently and attentively listening to Sugiharti's complaints without even once touching his food. This perspective, of course, invites the viewers to delve into Tan Ging Le's unspoken thoughts and feel his mutual respect towards Sugiharti. This is where the filmmaker attempted to instill drama into the story, which is achieved by means of point of view than with a dialogue. Camera movement is another element which successfully delivers Sugiharti's confusion of her Chinese Indonesian identity into the screen. The majority of scenes are minimally shot from the same angle with occasional changes on the camera framings like medium shot and extreme close-ups which are aimed to highlight the characters' emotions (Lewis, 2014). The camera angle was somewhat concentrated to Tan Ging Le and Sugiharti, in a medium shot suggesting their mutual standing/position as a fellow Chinese Indonesian. Alternatively, the shots were taken at a different angle for Sugiharti's pribumi dates. For instance, the medium long shot taken at Sugiharti and her pribumi dates, establishing a sense of resistance between them. The choice of medium long shot in this sense is crucial for translating the boundary of "us and them" the pribumi dates feel towards Sugiharti.

Additionally, it also addresses the exclusiveness/ racial superiority of the Chinese compared to other ethnic and also the racial hierarchy positioning Chinese above the pribumi that is distributed in inter-ethnic daily discourse (Kuntjara \& Hoon, 2020). Sugiharti, however, is often shot in extreme close-up to indicate that she is the focal point, through which the story of her Chinese identity is told. The camera occasionally moves from medium close-up to extreme close-up, highlighting Sugiharti's facial expression, her rebellious and inner rage.

Tan Ging Le, on the other hand, was so much calmer in his countenance. He responded the issue over his Chinese identity more positively because he knows that there will be no end to the problem of Chinese identity; however, one cannot simply run away from one's cultural roots simply by changing one's name, to Indonesian or western name, the culture will remain and become the identity through which one is known by others (Lie $\&$ Bailey, 2017). The final shot was directed back at Sugiharti, displaying her "defeated"/" submissive" expression in a close-up framing, upon hearing Tan Ging Le's testimony, hinting at a rather satisfying ending of the film.

\section{Underpinning Sugiharti's Ambiguous Identity by means of Costumes and Make up}

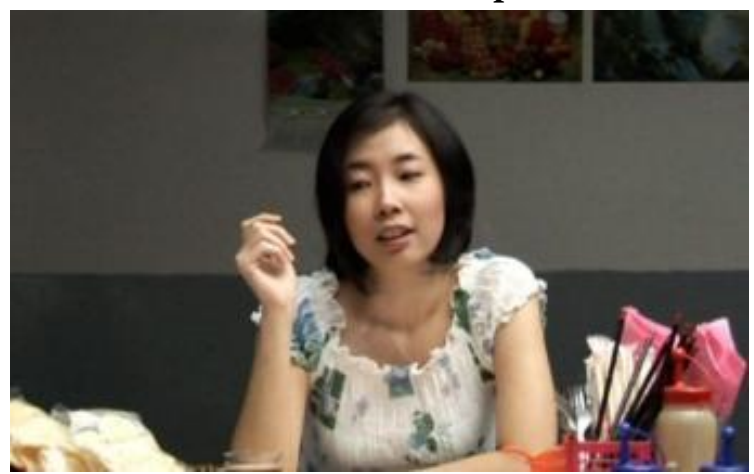

Figure 8. a movie still displaying the first costume Sugiharti wears on her first date with a pribumi

Costume and make-up is the final element of mise-en-scene which also helps translate the issue of Sugiharti's ambiguous identity. Costume and make-ups are typically the filmmaker's secret toolkit to create a certain character, enhance the characterization or even communicate the characters' standpoints (Lewis, 2014). 


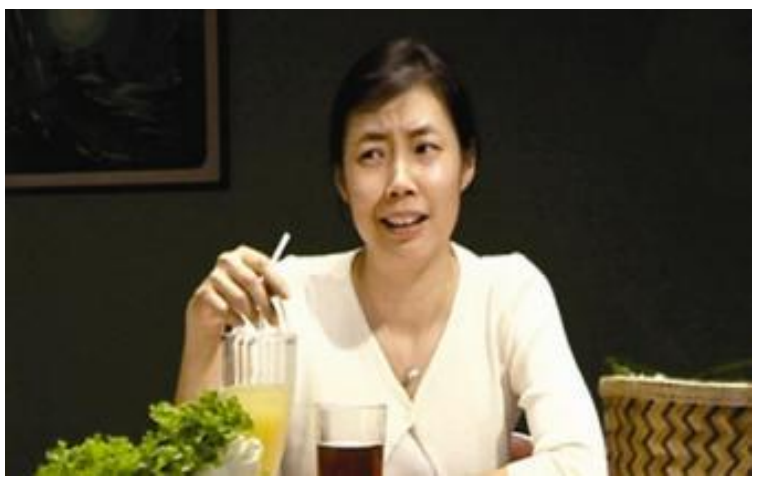

Figure 9. a movie still displaying the second costume Sugiharti wears on her second date with a pribumi

Upon meeting her first pribumi date, for instance, Sugiharti is dressed in a rather feminine and elegant outfit, with only minimal "no makeup" make up and a girlish haircut. However, as she switches date to another pribumi, she dresses down in a less feminine-casual outfits. Her hair, on the other hand, is also not as neatly done as in the previous date. On the third and final date, with Tan Ging Le, she is only dressed in a simple blouse, with no makeup on her face. The change of Sugiharti's costumes brings forth various interpretation from the viewers. On the one hand, the filmmaker hinted at the unspoken sense of exclusiveness circulating around the Indonesian society giving the impression that those of Chinese descend are somewhat more superior in all aspects compared to their non-Chinese competitors (Kuntjara \& Hoon, 2020).

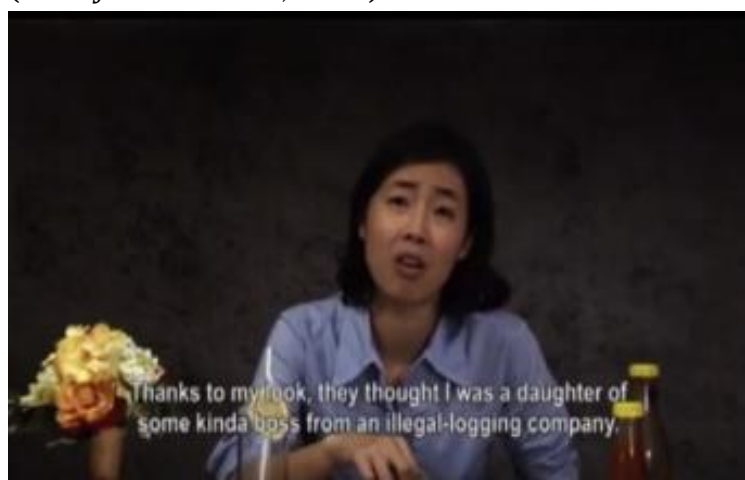

Figure 10. a movie still displaying the final costume Sugiharti wears on her date with Tan Ging Le

Therefore, the pribumi dates feel rather reluctant to interact with Sugiharti during the dinner date and opt to withdraw from the relationship. Sugiharti, too, is aware of the gesture, that she will less likely bet her chance at dating a pribumi guy. On the other hand, the final costume she wears does not signify her sense of defeat/despair upon not being able to get her date's attention. The simple blouse may suggest an air of familiarity/comfort for being around her own people - a fellow Chinese Indonesian guy. Therefore, she does not need to dress so excessively to get his attention.

She is also well aware that she is somewhat free to date any guy, be it a Pribumi or a Chinese Indonesian, but at the end of the day, she would have to find a Chinese husband as the majority of Chinese parents would opt to marry their daughter to men from the same ethnicity, for the sake of retaining their Chinese custom and avoiding past trauma for social friction with the non-Chinese (Kuntjara \& Hoon, 2020). The choice of costume and make-up in this respect is rather intended to communicate Sugiharti's view of her Chinese identity and the consequence of her being a Chinese Indonesian. With no emphasis on the dialogue, the choice of costumes and make-ups informs the viewers of the characters' attitudes. As Sugiharti moves from one dinner date to another, the costume and make-up also helps builds up the tension, advancing the plot further to its resolution with Tan Ging Le's story.

\section{CONCLUSION}

Sugiharti Halim metaphorically stands for the most anticipated return of Chinese Indonesian filmmakers in the national cinema. The Chinese Indonesian filmmaker, Ariani Darmawan has offered a fresh new breath in the cinematic portrayal of Chinese Indonesians by bringing up the less exposed issue of assimilation policy. Sugiharti Halim brilliantly captures the main character's concern and discontentment over her silly sounding Indonesian name which situates her and fellow Chinese Indonesians in the most vulnerable position. This is especially highlighted by the use of montage sequences throughout the film, displaying fragments of ethnical prejudices and stereotypes and also some artefacts of sentimental values to older generation of Chinese 
Indonesians (SBKRI/Surat Bukti Pergantian Nama) which, in all respects, represents her invisible marker as a liyan/perpetual foreigner in the eyes of the pribumi. The simple camera works and mise-enscene helps intensify the issue despite the limitation of the cinematic medium, making this short film somewhat grander than its cinematic packaging. The choice of genre also contributes to the delivery of such sensitive issue, in which case the light, cynical humor helps make the $40+$ history of Chinese Indonesians more digestible to most viewers. The writer would like to conclude that the strength of this short film lies not in the complexity of its filming techniques, but more in its narration (which is enhanced by the use of montage sequence and mise-en-scene), as do any other indie/short films which put more investment on the delivery of film narration and theme rather than the techniques. (Setijadi, 2013). Sugiharti Halim, all in all, is a new means for rectifying the misconstrued ideas and stereotypes surrounding the discourse of Chinese Indonesian identity and helping the younger Chinese Indonesian filmmakers to reconnect and this time "properly" re-express their Chinese cultural heritage which was previously suppressed or pre-conditioned by the anti-Chinese government. Sugiharti Halim encompasses individuals' strong bond to their cultural roots, that no matter how local/western their names are; they will never fully escape from their true, cultural identity as Chinese Indonesians. As quoted from Shakespeare in Tan Ging Le's final remark: "What's in a name, that which we call a rose by any other name would smell as sweet." (Romeo and Juliet, Act 2, Scene 2).

\section{REFERENCES}

Bordwell, D., Thompson, K., \& Smith, J. (2013). Film Art: An Introduction. McGraw Hill Education.

Darmawan, A. (director). (2008).Sugiharti Halim. (Independent Film). Kineruku Production.

Hoon, C.-Y. (2017). Between Hybridity and Identity: Chineseness as a Cultural Resource in Indonesia. 32,
167-182. https://doi.org/10.1007/978-981-336096-9_9

Kuntjara, E., \& Hoon, C. Y. (2020). Reassessing Chinese Indonesian stereotypes: two decades after Reformasi. South East Asia Research, 28(2), 199-216.

https://doi.org/10.1080/0967828X.2020.17296 64

Lewis, J. (2014). Essential Cinema: An Introduction to Film Analysis.

Lie, S., \& Bailey, B. (2017). The power of names in a Chinese Indonesian family's negotiations of politics, culture, and identities. Journal of International and Intercultural Communication, 10(1), 80-95. https://doi.org/10.1080/17513057.2016.1 216577

Nuraeni, D. M. (2017). Representasi Identitas Perempuan Dalam Film Independen Sleep Tigh, Maria Dan Sugiharti Halim Karya Perempuan Sutradara. Universitas Airlangga, 53(9), 16891699. http://repository.unair.ac.id/70583/

Rokhani, U. (2020). The Strategy to Address "Chinese"-Ness Theme in Indie Movie in Post New Order Era. 1, 444455. https://doi.org/10.5220/0009395404440455

Seeman, M. V. (1980). Name and identity. Canadian Journal of Psychiatry, 25(2), 129-137. https://doi.org/10.1177/070674378002500206

Setijadi, C. (2013). Chinese Indonesians Reassessed (S. MinSiew \& C.-Y. Hoon (eds.)). Routledge.

Setijadi, C. (2016). 'A beautiful bridge': Chinese Indonesian associations, social capital and strategic identification in a new era of China Indonesia relations. Journal of Contemporary China, 25(102), 822-825. https://doi.org/10.1080/10670564.2016.11848 95

Thaniago, R. (2017). Disciplining Tionghoa (p. 14). Lund University.

Watzlawik, M., Silva Guimarães, D., Han, M., \& Jung, A. J. (2016). First Names As Signs of Personal Identity: An Intercultural Comparison. Psychology \& Society, 8(1), 1-21. http://www.psychologyandsociety.org/ assets/ original/2016/06/1 names.pdf

Wulia, T. (2008). The Name Game. Inside Indonesia, 110. https://www.insideindonesia.org/thename-game 